Yale Language Series 

EDITED BY PETER C. PATRIKIS

\section{Reading Between the Lines}

PERSPECTIVES ON FOREIGN

LANGUAGE LITERACY

Yale University Press

New Haven \&

London 
Copyright (C) 2003 by Yale University.

All rights reserved.

This book may not be reproduced, in whole or in part, including illustrations, in any form (beyond that copying permitted by Sections 107 and 108 of the U.S.

Copyright Law and except by reviewers for the public press), without written permission from the publishers.

Publisher:

Mary Jane Peluso

Editorial Assistant: Emily Saglimbeni

Manuscript Editor: Jane Zanichkowsky

Production Editor: Margaret Otzel

Marketing Coordinator: Tim Shea

Production Coordinator: Joyce Ippolito

Set in Minion type by Keystone Typesetting, Inc.

Printed in the United States of America.

Library of Congress Cataloging-in-Publication Data

Reading between the lines : perspectives on foreign language literacy /

edited by Peter C. Patrikis.

p. cm. - (Yale language series)

Includes bibliographical references and index.

ISBN 0-300-09781-6 (pbk. : alk. paper)

1. Language and languages-Study and teaching. 2. Literacy-Study and teaching.

I. Patrikis, Peter Charles. II. Series.

P53.475.R43 2003

$418^{\prime} .0071-\mathrm{dc} 21$

2002033171

A catalogue record for this book is available from the British Library.

The paper in this book meets the guidelines for permanence and durability of the Committee on Production Guidelines for Book Longevity of the Council on Library Resources.

$\begin{array}{llllllllll}10 & 9 & 8 & 7 & 6 & 5 & 4 & 3 & 2 & 1\end{array}$ 
... et femina dux erat

To Claire Kramsch

for leading the way 
